УДК 655.3.066.11:655.335

\title{
ТРАФАРЕТНИЙ ДРУК ЯК ТЕХНОЛОГІЯ ВИГОТОВЛЕННЯ ТАКТИЛЬНИХ КНИГ
}

\author{
( М. Т. Мотика, аспірантка, УАД, Львів, Україна \\ Осуществлен анализ технологических схем \\ изготовления тактильных книг для незрячих.
The analysis of flowsheets of making haptic books for blind people is carried out.

\section{Постановка проблеми}

Поповнення та удосконалення наявного асортименту різноманітних способів створення видань для незрячих розширює можливість забезпечення останніх необхідною інформацією, адже, як свідчить аналіз літературних джерел, проблема її доступності постійно супроводжує людей 3 вадами чи повною відсутністю зору. Питання виготовлення літератури спеціального призначення надзвичайно актуальне і підкріплене стрімким розвитком технологічних рішень у галузі поліграфії. У ряді публікацій розглядаються технології виготовлення тактильних зображень [2-4, 6], однак не здійснюється техніко-економічний аналіз сучасних способів їх одержання. 3 огляду на це важливим $€$ визначення основних технологічних особливостей найпоширеніших способів виготовлення тактильних книг, реалізація яких може стати суттєвим кроком в інтеграції незрячих дітей у світі.

\section{Мета роботи}

Здійснити аналіз технологічного процесу виготовлення так- тильних книг за допомогою аплікацій, методом тиснення, трафаретним та струминним способами друку.

\section{Результати проведених} аналітичних досліджень

Найголовнішою вимогою одержання якісних тактильних зображень для незрячих осіб є дотримання відповідних критеріїв вибору методів їх виготовлення (рис. 1), викладених у наших та публікаціях інших авторів (доцільність використання тієї чи іншої технології повинна бути оцінена з точки зору забезпечення необхідних вимог і виконання визначених функцій) [8, 12, 13].

Як показує аналіз літературних джерел, найбільшого поширення, завдяки перевагам у доступності матеріалів та устаткування, набули такі технології виготовлення тактильних книг (рис. 2), як: використання аплікацій, трафаретний і струминний друк, метод тиснення. За джерелами [5, 7, 9-11] проаналізовано технологічні процеси виготовлення тактильних книг вищезазначеними способами (рис. 3). 
Критерії вибору

Висота рельєфу

Характеристика профілю елемента

Адгезія рельєфних елементів до матеріалу основи

Стійкість до стирання під дією пальців

Довговічність

Тактильні відчуття

Тиражестійкість

Кількість задруковуваних сторін аркуша

Кількість можливих для відтворення кольорів

Механізація технологічних операцій

Витрати на виробництво

Час, необхідний для друку одного примірника

Рис. 1. Критерії вибору оптимальної технології виготовлення тактильних зображень 


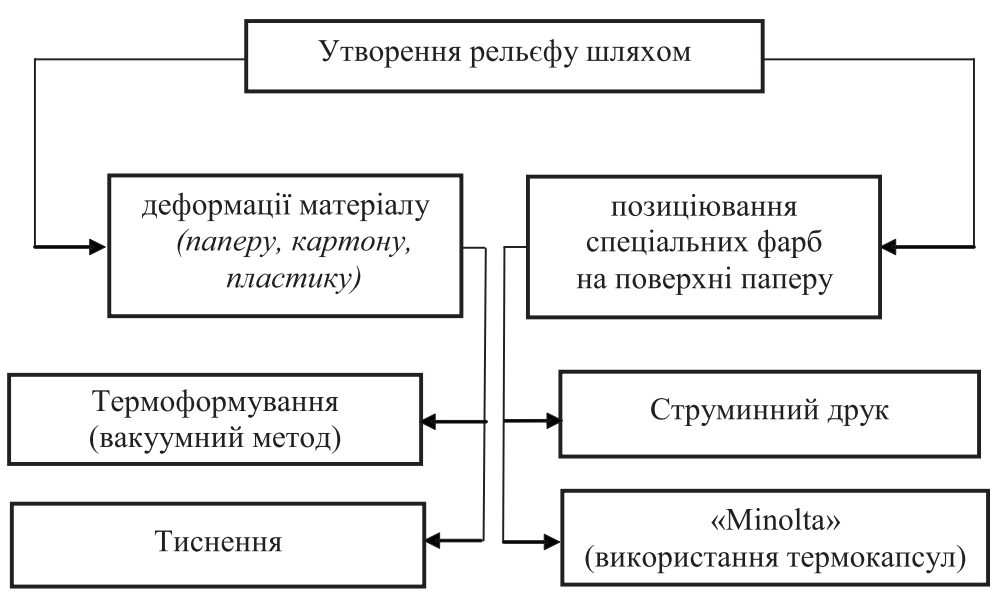

Рис. 2. Класифікація способів одержання рельєфних зображень

Технологічний процес виготовлення тактильних книг включає такі операції: Т1 - створення дизайну майбутнього видання; Т2 - підготовка текстової та ілюстраційної інформації: уведення, коректура, верстка; Т3 - одержання екранної та цифрової кольоропроби; Т4, Т6, Т23, Т28, T31, Т35 - контроль якості; Т5 електронний монтаж; Т7 - кольороподіл; Т8 - вивід фотоформ; Т9 - підготовка матеріалів; Т10 натягування сіткової тканини; Т11 - підготовка поверхні сітки до нанесення копіювального шару: знежирювання, промивання, сушіння; Т12 - нанесення копіювального шару на сітку; Т13 сушіння; Т14 - поміщення плівки на трафаретну форму; T15 копіювання зображення; Т16 проявлення копії; Т17 - сушіння та коректура форми; Т18 контроль якості та коригування форми; Т19 - підготовка матеріалів і машини трафаретного друку; Т20 - приводка і регулювання ракельного механізму; Т21 - друкування накладу пластизолевими фарбами; Т22 сушіння відбитків; Т24 - підго- товка матеріалів і машини струминного друку; Т25 - вивід інформації; Т26 - виготовлення друкарської форми за технологією Ctp; Т27 - корекція зображення на пластині; Т29 - підготовка матеріалів і машини офсетного друку; Т30 - друкування накладу; Т32 - підготовка матеріалів і лазерного гравера; Т33 - гравіювання; Т34 - обробка пластини; Т36 - тиснення; Т37 - друкування крупнокегельного тексту та шрифту Брайля; Т38 - розрізування віддрукованих аркушів; Т39 - виготовлення викройок окремих деталей; Т40 - прикріплення аплікацій до сторінок клеєм, липкою стрічкою та нитками; Т41 - виготовлення обкладинки; Т42 підбирання розрізаних аркушів; Т43 - скріплення блока механічним способом.

Використовуване устаткування (у кожному конкретному випадку його вибір залежить від обраного технологічного рішення): У1 - персональний комп'ютер; У2 - цифрова система кольоропроби; УЗ - фотопроцесор; у4 - пневматичний натяжний 


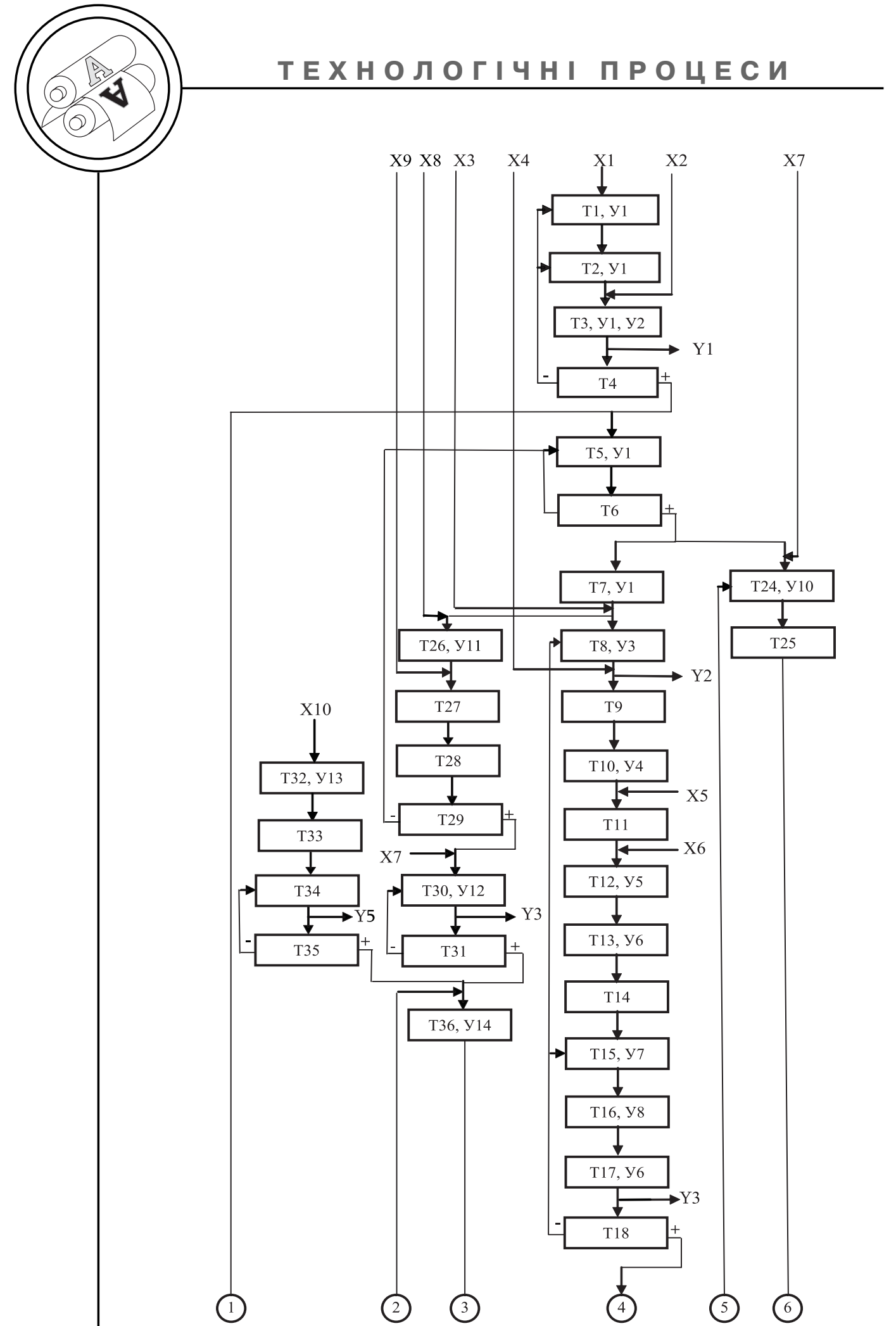

Рис. 3. Блок-схема комплексного технологічного процесу виготовлення тактильних книг. Початок 

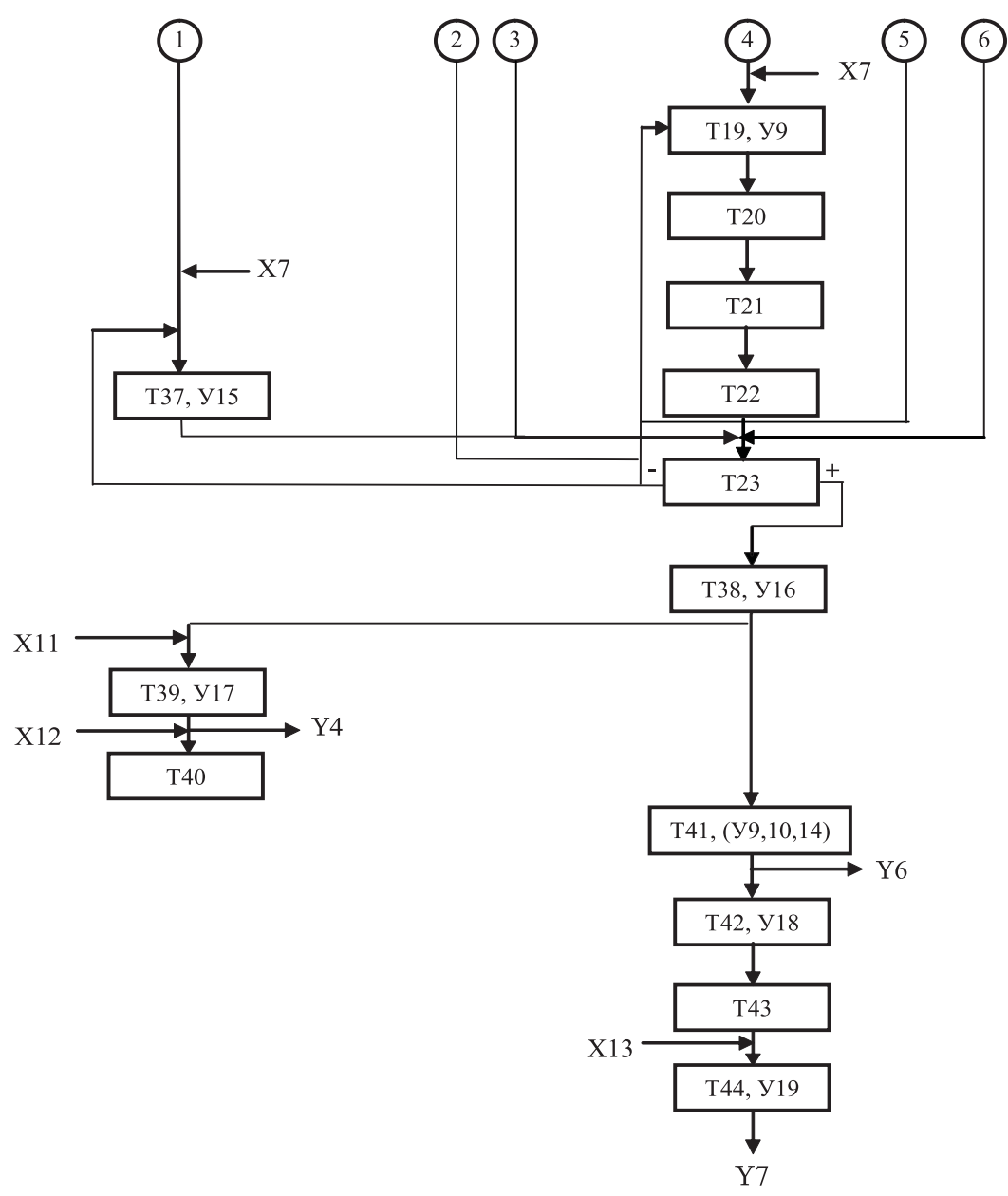

Рис. 3. Блок-схема комплексного технологічного процесу виготовлення тактильних книг. Закінчення

пристрій; У5 - ракель-кювета для нанесення світлочутливої емульсії; У6 - сушильна шафа; У7 - копіювальна рама; У8 проявна ванна; у9 - машина трафаретного друку; У10 - машина струминного друку; У11 система для прямого експонування пластин; У12 - машина офсетного друку; У13 - лазерний гравер; У14 - прес для тиснення; У15 - устаткування для друкування звичайного тексту та шрифту Брайля; У16 - різа- льна машина; У17 - інструменти для виготовлення викройок (ножиці, лінійки); У18 - підбиральна машина; У19 - біндер.

Вхідні дані: X1 - оригінали тексту та ілюстрацій на прозорій і непрозорій основах; X2 - витратні матеріали для цифрової кольоропроби; ХЗ - витратні матеріали для виготовлення фотоформ (плівки, хімічні розчини); X4 - трафаретна сітка, рама; X5 - хімічні розчини, вода; X6 - копіювальний шар; X7 - 
папір, фарба; X8 - формні пластини, вимивні розчини; X9 коригувальні олівці і пасти; X10 пластина для гравіювання; X11 текстильні матеріали; X12 - витратні матеріали для приєднання аплікацій; X13 - витратні матеріали для механічного скріплення блока.

Вихідні дані: Ү1 - відбитки з кольоропроби; Ү2 - фотоформи; Ү3 - комплект друкарських форм; Ү4 - віддруковані аркуші; Y5 - кліше для тиснення; Y6 обкладинка; Ү7 - тактильна книга.

Як показує аналіз наведеної блок-схеми, найвдаліша реалі- зація вимог до тактильних книг забезпечується при їх виготовленні трафаретним способом друку, через що детальніше розглядається саме цей технологічний варіант [8]. Дана технологія базується на особливому принципі формування об'ємних елементів із спеціальної композиції фарб. Це означає, що шлях проходження фарби, її тип і властивості (наприклад, спінювання під час нагрівання) мають важливе значення (див. таблицю).

При трафаретному способі друку основою зазвичай обирають папір, але можна викорис-

Використання фарб для відтворення рельєфних зображень трафаретним способом друку

\begin{tabular}{|c|c|c|}
\hline Фарба & $\begin{array}{c}\text { Характеристика рельєфного } \\
\text { зображення }\end{array}$ & Особливі зауваження \\
\hline $\begin{array}{l}\text { Оксиполімери- } \\
\text { заційноздатні (на } \\
\text { масляній основі) }\end{array}$ & $\begin{array}{l}\text { високий глянець; } \\
\text { відчутний рельєф (за умо- } \\
\text { ви, що він спочатку ство- } \\
\text { рений на трафареті бага- } \\
\text { тократним нанесенням } \\
\text { копіювального шару вели- } \\
\text { кої товщини) }\end{array}$ & $\begin{array}{l}\text { значний час висихання; } \\
\text { друкування на невбирно- } \\
\text { му папері }\end{array}$ \\
\hline УФ-закріплення & $\begin{array}{l}\text { чітке вираження ефекту } \\
\text { рельєфності }(0,2-0,7 \text { мм); } \\
\text { високий глянець }\end{array}$ & $\begin{array}{l}\text { друкування на невбирно- } \\
\text { му папері; } \\
\text { наявність УФ-сушарки; } \\
\text { особливі режими сушіння: } \\
\text { зниження швидкості руху } \\
\text { транспортера, збільшення } \\
\text { потужності УФ-ламп; } \\
\text { наявність пристроїв для } \\
\text { видалення озону та захис- } \\
\text { ту працюючих }\end{array}$ \\
\hline $\begin{array}{l}\text { На основі розчин- } \\
\text { ників }\end{array}$ & $\begin{array}{l}\text { профіль елементу згла- } \\
\text { джений унаслідок роз- } \\
\text { тікання фарби в процесі } \\
\text { сушіння; } \\
\text { незначна висота рельєфу } \\
\text { в результаті випаровуван- } \\
\text { ня 60 \% об'єму фарби } \\
\text { при їі закріпленні; } \\
\text { добра адгезія до основи }\end{array}$ & великі витрати фарби \\
\hline
\end{tabular}


товувати і багато інших матеріалів, у тому числі картон, пластик і текстильні матеріали, що сприяє розширенню сфери використання цього методу. Основні кошти витрачаються в основному на виготовлення трафаретної форми. Сітку для її виробництва обирають відповідно до розмірів елементів зображення. Але в будь-якому випадку рельєфне зображення не може містити надто дрібні деталі. Ефект рельєфності досягається за рахунок використання сіток низьких лініатур, великої товщини копіювального шару на формі, друку в кілька прогонів з проміжним сушінням відбитків [1].

Відомо кілька технологій відтворення рельєфних зображень трафаретним способом друку (рис. 4).

При обробці віддрукованої поверхні відбитка спеціальним термочутливим порошком на покритих фарбою ділянках відбу- вається часткове його закріплення, решта видаляється струменем повітря. Віддрукований аркуш піддають тепловій обробці, у результаті чого гранули порошку набухають й утворюють рельєф необхідної висоти (близько 0,5 мм), однак контури окремих елементів $€$ більш округленими і нечіткими. Крім того, виявлено, що зображення, виконані таким способом, неприємні на дотик.

При друкуванні термочутливими фарбами аркуш паперу піддають тепловій обробці для ії сплавлення та утворення рельєфу. Цей метод простіший. Рельєф утворюється, як правило, задовільної якості, хоча профіль інколи надто округлий, не виникає проблеми ефекту рваних країв, оскільки гранули барвника плавляться, утворюючи кілька нерегулярних структур, простіших для тактильного розпізнавання. До того ж витрати на виробництво значно нижчі. Недоліком да-

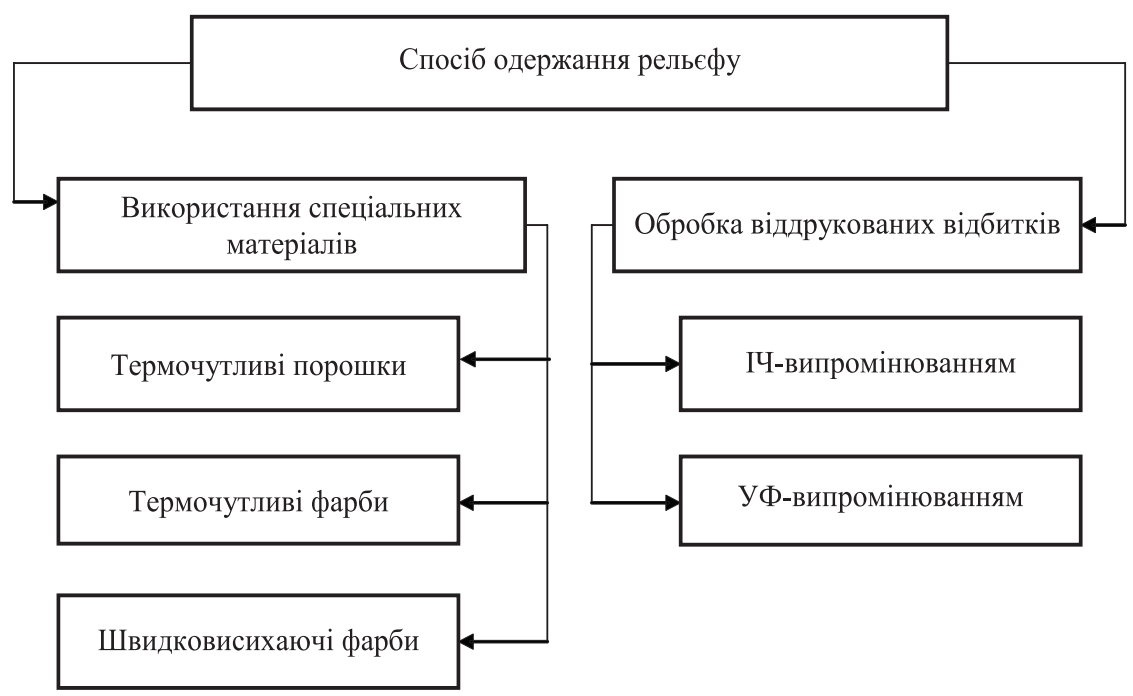

Рис. 4. Класифікація технологій відтворення рельєфних зображень трафаретним способом друку 
ного методу $є$ недостатня адгезія фарби до поверхні паперу та її вищипування в майбутньому.

Використання швидковисихаючих фарб, які самі і формують рельєф після сушіння в камері, - процес відносно дешевий, бо матеріали, що додають у фарбу для підвищення в'язкості, не дуже дорогі. Рельєф формується задовільної якості: профіль набагато гостріший; висота рельєфу достатня для передачі необхідної інформації, проте виникають складності з виділенням дрібних точок і тонких ліній; хороша адгезія до паперу чи іншої основи. Тактильні відчуття одержаних рельєфних зображень можуть бути скориговані шляхом зміни складу речовин, що додаються до фарби [13].
Як і всі методи, при яких фарбовий шар наносять на матеріал-основу, а не деформують іiі, трафаретний спосіб друку забезпечує друкування з обох сторін аркуша. Отже, як стає помітно, дослідження використання технології трафаретного друку при виготовленні спеціальних видань для незрячих $€$ досить перспективним науковим напрямком.

\section{Висновок}

Описано найбільш поширені технології виготовлення тактильних книг для незрячих дітей.

Детально розглянуто особливості застосування трафаретного способу друку для відтворення рельєфних зображень.

1. Бригінець Л. Товщина фарбової плівки на відбитках трафаретного друку / Бригінець Л. // Друкарство. - 2002. - № 4. - С. 68-70. 2. Вакуліч Д. А. Видання для незрячих: нотатки з Республіканського будинку звукозапису і друку / Вакуліч Д. А. // Print Plus. - 2007. - № 4. - C. 66. 3. Вакуліч Д. А. Допоможіть відкрити світ людям з обмеженням зору / Д. А. Вакуліч, В. 3. Maïк // Print Plus. - 2007. - № 4. - C. 62-65. 4. Вакуліч Д. Дослідження паперів та картонів, призначених для виготовлення видань для незрячих / Д. Вакуліч, Н. Цуца // Квалілогія книги. - Львів : УАД, 2007. - № 2(12). С. 67-72. 5. Демянишин Д. В. Широкоформатний струминний друк / Демянишин Д. В., Нетак В. Б., Лазаренко Е. Т. - Львів: ПромІНФО, 2010. - 80 с. 6. Кілко І. Нанесення інформації для незрячих на пакувальні матеріали / I. Кілко, В. Степанець // Упаковка. - 2007. - № 2. - С. 50-52. 7. Маїк В. 3. Тиснення: технології, матеріали, устаткування / Маїк В. 3. - Львів : НВП «Мета», 1997. - 176 с. 8. Мотика М. Тактильна книга: аналіз функцій, вимог, технологій виготовлення / М. Т. Мотика, Е. Т. Лазаренко // Квалілогія книги. Львів : УАД, 2010. - № 2(18). - С. 56-63. 9. Полянський Н. Н. Технология формных процессов : учеб. / Полянский Н. Н., Карташева О. А., Надирова Е. Б. - М. : МГУП, 2010. - 366 с. 10. Слоцька Л. С. Трафаретний друк: формні процеси / Слоцька Л. С. - Львів : НВП «Мета», 1999. - 122 с. 11. Ткачук М. П. Трафаретний друк : навч. посіб. / Ткачук М. П. - К. : ХаГар, 2000. - 264 c. 12. Edman P. K. Tactile Graphics / P. K. Edman. - New York: American Foundation for the Blind, 1992. 13. Using silk screen printing for relief drawings: Examples from guides to Turin and Venice - [Електронний ресурс] Режим доступу : www.tactilevision.it/approfondimenti/Parigi-en.pdf. 